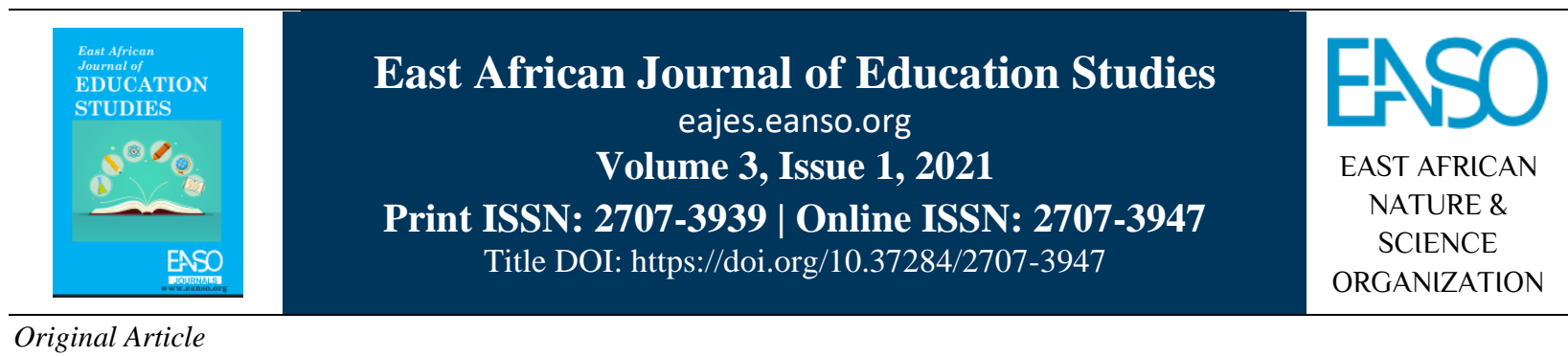

\title{
Availability of Physical Infrastructure in Implementation of the Competence-Based Curriculum in Public Primary Schools in Kericho County
}

\author{
Beatrice Ngeno ${ }^{* 1}$ Dr. Maureen Mweru \& Dr. Teresa Mwoma ${ }^{1}$ \\ 1* Kenyatta University, P. O. Box 43844-00100, Nairobi, Kenya. \\ * ORCID: https://orcid.org/0000-0002-3329-7168; Correspondence Email: ngenoc.beatrice@ gmail.com.
}

Article DOI: https://doi.org/10.37284/eajes.3.1.344

\section{Date Published: ABSTRACT}

14 June 2021 A competency-based curriculum is a curriculum that allows students to develop prescribed competencies. In Kenya, the Competence-Based Curriculum

Keywords: implementation of 2-6-6-3 was adopted in January 2017. This education system replaces the 8-4-4 system of education and it aims to nurture the learners

Physical 'talents. School preparedness for the new curriculum change in Kenyan public

Infrastructure, primary schools is very important in the education policy framework. When

Competence-Based curriculum change takes place in education, teachers as instructors and implementers should be supported to be competent in their work. The educators

Curriculum,

Descriptive Survey, have a responsibility to ensure that today's learning content meets tomorrow's

Correlation Design. global demands for every learner. However, in Kenya, various stakeholders have expressed concerns regarding school and teachers' preparedness for the Competence-Based Curriculum. The objective of the study was to find out whether there is a relationship between the availability of physical infrastructure and the implementation of the competency-based curriculum. Dewey's Social Constructivism theory guided the study. A descriptive survey design was used in this study. The target population of the study included 24 County Support Officers (CSOs'), 524 head teachers, and 610 Grade 1 teachers. The sample size was 6CSOs, 52 Head teachers, and 61 Grade 1 teachers. A saturated sampling technique was used to select all the 52 head teachers from 52 schools. Simple random sampling was used to select the schools and CSOs. A purposive sampling technique was used to select Grade 1 teachers in Kericho County. Data was collected using interview schedules, questionnaires, and an observation schedule. Quantitative data were analysed using descriptive statistics in the form of percentages, means, and standard deviation, while inferential statistics were correlated using Pearson product-

$130 \mid$ This work is licensed under a Creative Commons Attribution 4.0 International License. 
moment correlation. Qualitative data was analysed using themes and subthemes. The findings established that physical infrastructure had a moderate positive influence on CBC implementation with a correlation of 0.336 and a calculated value of 0.029 for the head teachers and 0.285 with a calculated value of 0.03 for Grade 1 teachers. Shortage of physical infrastructures like nutrition rooms and music rooms had a mean of 2.18 and 1.88 for head teachers. Grade 1 teachers' response was 1.39 and 1.35 for nutrition and music laboratories respectively. The findings of the head teachers on teacher preparation had a moderate positive influence on CBC with a correlation of 0.494 with a calculated $p$-value of 0.00 . The teachers had a correlation of 0.369 with a calculated p-value of 0.005 and were significant to the study. The study recommended that there is need for government to increase funds to enable schools to construct laboratories.

\section{APA CITATION}

Ngeno, B., Mweru, M. \& Mwoma, T. (2021). Availability of Physical Infrastructure in Implementation of the CompetenceBased Curriculum in Public Primary Schools in Kericho County. East African Journal of Education Studies, 3(1), $130-145$. https://doi.org/10.37284/eajes.3.1.344.

\section{CHICAGO CITATION}

Ngeno, Beatrice, Maureen Mweru and Teresa Mwoma. 2021. "Availability of Physical Infrastructure in Implementation of the Competence-Based Curriculum in Public Primary Schools in Kericho County”. East African Journal of Education Studies 3 (1), 130-145. https://doi.org/10.37284/eajes.3.1. 344.

\section{HARVARD CITATION}

Ngeno, B., Mweru, M. and Mwoma, T. (2021) "Availability of Physical Infrastructure in Implementation of the CompetenceBased Curriculum in Public Primary Schools in Kericho County”, East African Journal of Education Studies, 3(1), pp. 130-145. doi: 10.37284/eajes.3.1. 344.

\section{IEEE CITATION}

B. Ngeno, M. Mweru, and T. Mwoma, "Availability of Physical Infrastructure in Implementation of the Competence-Based Curriculum in Public Primary Schools in Kericho County”, EAJES, vol. 3, no. 1, pp. 130-145, Jun. 2021.

\section{MLA CITATION}

Ngeno, Beatrice, Maureen Mweru and Teresa Mwoma. "Availability of Physical Infrastructure in Implementation of the Competence-Based Curriculum in Public Primary Schools in Kericho County". East African Journal of Education Studies, Vol. 3, no. 1, Jun. 2021, pp. 130-145, doi:10.37284/eajes.3.1.344.

\section{INTRODUCTION}

A competence-based curriculum (CBC) is a set of courses, which promote learning areas in which the learner is gifted and skilled. Jadhav and Patankar (2013) defined curriculum implementation as a participatory process that needs an all-inclusive approach. Therefore, all stakeholders are brought on board for its successful implementation. Implementation takes place as the learner acquires the expertise, abilities, ideas and attitudes expected or anticipated to enable the same learner to work efficiently in a community. A study done in Canada by Christensen and Lane (2016) on a change in standard awareness dependent on the demonstration of education skills led to the creation of more learning opportunities for all learners. This study further pointed out that the Canadian government implemented the CBC in 1992 (Forum for Research and Policy in Communication - FRPC, 2020). Technology, Reading and Mathematics were also successfully completed in the United States on a Programme for International Student Assessment (PISA) tests. The government of Scotland also implemented the competence-based curriculum and the evaluation was above average on PISA tests which were successful (Michel, 2017). Competence-based in Finland was successful and ranked top globally in 2016. 
According to Wanjohi (2018), the 8-4-4 system was based on the national goals of education, amongst them, promoting national growth, social, economic, technical, and industrial needs. Secondly, it was to encourage human growth and self-fulfilment, talents, and gifts for learners of Kenyan citizens. Thirdly was to promote religious values and sound morals. Unfortunately, these aims were not fully satisfied because of massive exam irregularities and non-self-reliant citizens. Council of Governors with support of the Ministry of Education and the Kenya Institute of Curriculum Development have been providing technical support to the County Governments in the implementation of competencebased curriculum (2-6-6-3) to achieve the targets that were not met by the 8-4-4 curriculum (Council of Governors, 2019) According to KICD (2017), the new curriculum adopted four levels of learning including early year's education, middle-level education, and tertiary and university level. The early years are broken down into pre-primary and lower primary education. The pre-primary level is further broken down into Pre-primary one and Preprimary two. Learners then proceed to Lower Grade, where the learners spend three years in this level. Later, the learners join a middle school which comprises three years in upper primary and proceed to junior secondary level. At this level, the learners are given an opportunity to realise their abilities and interests where they are guided in choosing the subjects in relation to career directions at the senior secondary school. The new system relies on the cumulative evaluation from the continuous assessment tests administered at all levels. The learners later proceed to tertiary institutions of higher learning which consist of undergraduate, Technical, Vocational Education Training (TVET) and diploma programs (Republic of Kenya, 2017). It further pointed out that a competency-based approach allows meaningful ties through a focus on skills within and across subject areas.

In $\mathrm{CBC}$, subjects continue to be taught and this shows that core competencies are generated over time. The subjects that are taught in lower primary are Literacy, Kenya sign language, Kiswahili language activities purposed for deaf learners' mathematical activities, nutrition and hygiene activities environmental activities, indigenous activities, creative activities and movement and religious education activities. It is expected then that by the end of early year's education (Grade 1 to Grade 3), the learner will have achieved skills learning as follows:

- Demonstrate basic academic skills in reading and numeracy.

- Communicate appropriately in a number of situations using verbal and/or non-verbal forms.

- Demonstrate adequate social relationship etiquette; use imagination and logical thought capabilities to overcome problems.

- Explore the instant learning and entertainment world.

- Hygiene, diet, hygiene and protection skills are taught to enhance well-being and health.

- Demonstrating the acquisition for healthy living of mental, spiritual, physical, spiritual, aesthetic and moral development.

- Demonstrate the appreciation for harmonious coexistence of the rich and varied cultural heritage of the country.

- Apply digital literacy skills for enjoyment and learning.

Notably, the above studies did not address schools' preparedness for the competence-based curriculum. It is important for schools to be well prepared to embrace the competence-based curriculum, as this approach allows meaningful ties through a focus on skills within and across subject areas. The current study sought to find out the physical infrastructure on the competence-based curriculum in public primary schools in Kericho County. The research objective was to find out whether there is a relationship between the availability of physical infrastructure and the implementation of the competency-based curriculum in public primary schools in Kericho County.

\section{LITERATURE REVIEW}

\section{Dewey's Social Constructivism}

Dewey (1938) suggests that the learning environment can create a learner who can cope 
successfully with new developments around the world. Therefore, the program should not be viewed as completed abstractions but rather as a preconception of the learner. It can strengthen the understanding of how the infant understands his or her attitudes to worlds, different of them are used. Dewey illustrated this theory with four instincts which include are social, constructive, expressive and artistic instincts which are in cooperated with CBC learning areas. Dewey related the subjects' area activities to learning life. He further noted that education is a growth where curriculum should arise from learners' interests to more practical learning of basic education in the curriculum. This theory supports continuous, participatory, and experimental learning hence; give light to practical learning of basic education. Therefore, this theory was relevant to this study because the current study focused on primary school preparedness which was the independent variable.

\section{Literature on Physical Infrastructure on Competence-Based Curriculum}

According to the World Bank (2019), the economy is evolving quickly in such a way that it is not enough to attend school. Learners should acquire fundamental skills and expertise in core subjects such as algebra, vocabulary, and science to excel in both life and career, and they must also learn how to communicate efficiently, how to solve challenges and work in teams. This agrees with the new CBC program in Kenya, where realistic orientation is required for learners. This is crucial to improve human dynamics in successful societies. It will lead to thinkers and self-driven individuals. This calls for a curriculum that is relevant in this current century. European Union (2018) indicated that the curriculum for primary education in Greece is a thematic curriculum framework for compulsory education. This promotes cognitive interconnection of different subjects; hence, learners have a better understanding of concepts.

Hernández-de-Menéndez and Morales-Menendez (2017) pointed out that Competence-Based Education (CBE) individuals lack sufficient labour ability or potential. They continued that it is the presentation of experience encountered in schools or universities around the world. Good communication-critical thought and lifelong learning are the competencies that are facilitated. Activities in teaching practice are known as simulations and conditions in real life that are meant to be realistic. In terms of approaches to competence testing, multiple of them are used to guarantee the optimal degree of competence. Competence performance is ranked as pass or not pass and with transcripts of a narrative. The viewpoint of the CBE profit learner is also taken into account. The key function of CBE is that after a curriculum is completed, it weighs what a learner can do. It can also be modified at various levels by colleges or universities of varying ages/sizes depending on approaches and resources. However, CBE has given evidence to solve a worldwide challenge. This was in the supply and demand gap knowledgeable of personnel and can be managed if all responsible institutions cooperate.

Chaudhary (2015) pointed out that various factors affect the implementation of the curriculum, such as teachers, learners, ideology and cultural learning. It also revealed that the government provided physical amenities such as sports fields, workshops, libraries, classrooms, laboratories, and sports. For environment creation in curriculum, implementation can take place; the central government should be given physical facilities such as workshops, libraries, and classrooms, laboratories, and playing grounds. He added that the availability of quality materials and the availability of suitable amenities had a major impact on curriculum implementation.

Akomolafe and Adesua (2016) carried out a study on the Impact of Physical Facilities on sages of appraisal and performance in academics in senior secondary schools in southwest Nigeria. Kanyonga, Mtana and Wendt (2019) carried out a study on competence-based curriculum implementation in technical colleges in Arusha, Tanzania. The study was done to establish the trainers to implement the Competency-Based Education Training (CBET) curriculum. There was a need to prepare and equip the TVETs with the necessary materials and infrastructure for the transfer of skills and capabilities. It further pointed out that Tanzania's challenges included inadequate human resources and physical material for implementation. The training of teachers and instructors is very important to enhance the successful implementation of CBC. 
Nturibi (2015) did a study on school infrastructure influence on academic performance in public primary schools in Ruiru location, Kenya. The target of the study was 7 head teachers, 14 teachers, and 181 students from 7 public primary schools. The schools should also have well-equipped libraries hence the need to improve and equip libraries. The current study investigated CBC implementation in Kericho County.

Muasya and Waweru (2019) carried out a study on the constraints facing competence-based curriculum implementation in Machakos County, Kenya. Despite getting huge groups of students, most schools have had a crisis of staff shortages of insufficient laboratories and inadequacy of learning and teaching materials, among others.

Kigwilu and Akala (2017) carried out a study on the utilisation of resource implementation of the curriculum in Community Colleges in Kenya. The study examined how the current physical amenities and resources of learning and teaching are used by Catholic-sponsored community colleges in Nairobi for appropriate Artisan and Craft Curriculum Implementation. It was revealed that learning and teaching materials were inadequate. These included lecture halls, workshops and experimental training raw materials. The reference books were enough though still underutilised. Although there were inadequate playing grounds, insufficient course books and libraries, insufficient resources have been done through co-sharing agreements of signing related learning institutions on equipment local firms. The relationship of physical amenities on curriculum implementation is done by teachers. The highly-rated of influence of learning and teaching resources is done by both learners and teachers. The influence of teaching and learning resources on curriculum implementation has been highly rated by both students and teachers.

Ashiono (2018) carried out a study examining the factors that enhanced or hindered teachers' use of ICT in teaching numeracy skills. To perform this analysis, which initially gathered quantitative data, exploratory sequential mixed techniques were used. Qualitative and quantitative information was given. Both private and public primary schools in Mombasa County, Kenya were involved in the study. The findings of this study revealed that $4 \%$ of teachers used ICT regularly to teach numeracy concepts. This study concluded that the teachers' use of ICT in teaching numeracy concepts was inadequate in lower primary schools. The findings of the study were that most of the teachers were equipped inadequately to teach numeracy concepts by the use of ICT. The findings of the study were that accessibility of laptops and tablets by the teachers and learners in schools led to increased use of the ICT in teaching numeracy concepts.

A study was carried out by Ngeno, Sang, and Chemosit (2020) on selected primary schools on teacher computer literacy in Ainamoi Sub-County, Kericho County, Kenya. It demonstrated that the training of computer teachers that was completed in May 2015 did not appeal to all the teachers in the sector. The explanation was that head teachers and each school had two lower primary teachers who were ICT compliant. The study showed that teachers graduating from teacher training colleges in 2009 were also found to be computer literate among all teachers hired by the Teachers Service Commission (TSC) after 2006. The study found out that the government wants to conduct workshops and in-service services to cater to teachers who are still in the profession but are non-compliant with computers. The study proposed that teachers should be prepared to accept and adapt their teaching and learning with modern technologies. It also stated that to increase computer skills, ICT services and computer training should be enhanced forteachers. The Kenya Institute of Curriculum Creation should create a digital programming content guide to improve clear computer awareness. Examinable KNEC exams should be administered in teachers training colleges.

\section{RESEARCH METHODOLOGY}

The study utilised a descriptive survey design. The descriptive research design was useful for educational fact-finding because it provides a great deal of information (Kombo \& Tromp, 2006). The design was appropriate due to the allowance of questionnaires, interview schedule, and observation checklist instruments of research. Questionnaires were widely used frequently in the descriptive research design because they obtained facts about current conditions and were useful in making inquiries concerning their views and opinions 
(Kothari, 2004). The instruments gave the school head teachers, Grade 1 teachers and CSO officers enough time to give well-thought answers on the school preparedness in the implementation of CBC in public primary schools in Kericho County.

Both quantitative and qualitative techniques guide the study. Data collection methods included the use of questionnaires, which were both close and openended. The CSO's responded to an interview schedule. The observation schedule was used by the researcher to check on the physical infrastructure and teaching and learning resources found in schools.

The study population consisted of 524 head teachers, 610 Grade 1 teachers and 24 Curriculum support officers (CSO's) in Kericho County. The county has 524 public primary schools. The researcher purposed to select the Grade 1 teachers because they are experienced since they handle the learners through a competency-based curriculum system for the last three years. The Head teachers were also purposively selected for this study since they were the school administrators and they have experience on how the schools were prepared for the implementation of $\mathrm{CBC}$.

The instruments used included questionnaires, interview schedules and observation. The distribution of questionnaires was given to Grade 1 teachers and head teachers. Questionnaires were both open-ended and closed-ended.

\section{RESULT AND DISCUSSION}

Mean and standard deviation was used to analyse results from the Linkert scale. The mean ranking was derived from a scale of 1-5. Where strongly agree $=5$, Agree $=4$, undecided $=3$, disagree $=2$ and strongly disagree $=1$.

Table 1: Head teachers and Grade 1 Teachers Responses on Implementation of CBC

\begin{tabular}{|c|c|c|c|c|}
\hline \multirow[t]{2}{*}{ STATEMENTS } & \multicolumn{2}{|c|}{ Headteacher } & \multicolumn{2}{|c|}{ Grade 1 Teacher } \\
\hline & Mean & Std. Dev. & Mean & Std. Dev. \\
\hline $\begin{array}{l}\text { Learners demonstrate fundamental skills in literacy } \\
\text { and numeracy to learn }\end{array}$ & 3.70 & 1.11 & 3.72 & 1.06 \\
\hline $\begin{array}{l}\text { Learners interact appropriately in a number of ways } \\
\text { through verbal or non-verbal methods. }\end{array}$ & 3.61 & 1.19 & 3.04 & 1.02 \\
\hline $\begin{array}{l}\text { In social relationships, learners show acceptable } \\
\text { etiquette. }\end{array}$ & 3.24 & 1.22 & 3.04 & 1.30 \\
\hline $\begin{array}{l}\text { Creativity and critical reasoning skills in problem- } \\
\text { solving are beginners. }\end{array}$ & 3.86 & 1.23 & 3.79 & 1.03 \\
\hline $\begin{array}{l}\text { The immediate atmosphere for learning and } \\
\text { enjoyment is explored by learners }\end{array}$ & 2.18 & 0.92 & 2.81 & 0.77 \\
\hline $\begin{array}{l}\text { In order to improve health and well-being, learners } \\
\text { exercise hygiene, diet, sanitation and protection skills. }\end{array}$ & 2.70 & 0.97 & 1.72 & 1.01 \\
\hline $\begin{array}{l}\text { For the healthy life, learners show the acquisition of } \\
\text { mental, aesthetic, moral development, spiritual and } \\
\text { physical. }\end{array}$ & 3.34 & 1.10 & 3.02 & 1.22 \\
\hline $\begin{array}{l}\text { Learners express respect varied and rich cultural } \\
\text { heritage of the world for harmonious coexistence. }\end{array}$ & 1.24 & 1.19 & 1.04 & 1.28 \\
\hline $\begin{array}{l}\text { For learning and fun, learners apply digital literacy } \\
\text { skills. }\end{array}$ & 2.51 & 1.23 & 2.59 & 1.01 \\
\hline
\end{tabular}

According to Table 1, a competence-based curriculum was assessed indicating that the learners' skills and talents are catered for to a great extent. On demonstration of basic literacy and numeracy skills for learning, the head teachers rated it with a mean of $3.70(S D=1.11)$, while the Grade 1 teacher had a mean of $3.72(S D=1.06)$. Basic Literacy and numerical skills for learning have improved after the introduction of CBC. The Grade 1 teachers rated it slightly higher than the head 
teachers. The interview findings mentioned by the respondents indicated that with the CBC program, learners are able to read and solve mathematical problems comfortably. This is a clear indication that $\mathrm{CBC}$ has improved numeracy skills and basic literacy. This was clearly stated by a CSO, who said:

Since $C B C$ was started by the Kenyan government, the assessment of reading skills has improved among learners greatly. They are also self-driven and creative in their learning. This is an indication that reading has greatly improved. Therefore, there are chances of having a nation that is innovative and inventive.

This study concurs with the study done by UNESCO (2015) in Uganda, which found that many stakeholders are teachers in education whouse the thematic curriculum enhancing several powerful facets. These include enhanced significance, a stronger focus on skills of numeracy and literacy. It has also made the number of learners surge during classes, making learning a more exciting experience for children. Furthermore, it relates to the curriculum in Greece as indicated by the European Union (2018), where it noted that it promotes cognitive interconnection of different subjects; hence, learners have a better understanding of concepts. It also concurs with the study done by Vallejs, Morel, and Tusing (2017) in Russia on Competence-based program delivery. The study pointed out that the new approach to the competence_ based curriculum adopts interdisciplinary, dynamic process, contextualised, participatory and open advance pedagogical disciplines. The competency-based curriculum has improved participation in the teaching and learning process where skills and competence are reevaluated and developed to fit the local and global labour market. It also agreed with the study done in India by Chaudhary (2015), revealing that the curriculum should help the learner to acquire knowledge or experience in the learning process. Basing on the current study and other studies did elsewhere on curriculum; it is evident that a CBC should help to demonstrate basic literacy and numerical skills. The current CBC demonstrates these skills in Kericho County.

Learners interact appropriately in a number of ways through verbal or non-verbal methods which were one of the parameters that were used to measure $\mathrm{CBC}$. This was rated at a mean of $3.61(S D=1.19)$ by the head teachers and Grade 1 teachers rated at 3.04 ( $S D=1.02)$. The head teachers rated it higher than the Grade 1 teachers. Basing on the findings, learners were able to communicate well. This was further supported by the interview findings given by one of the CSO who stated that:

When the assessment is done, learners were able to communicate well for instance; they state their names and parents' names confidently. Communication skills were also acquired. The aspect of socialisation is good.

This is an indication that $\mathrm{CBC}$ is meeting the required outcome. This current study agrees with the findings by Hernández-de-Menéndez and Morales-Menendez, (2017), which pointed out that, in terms of competence assessment approaches, most of them are used to guarantee the desire competence level. Activities in teaching and practice are acquired through situations and simulations of real life. For the grading of exams and narrative transcripts, the performance of competencies was registered. This supports the assessment of CBC which is also relevant with this current study done in Kericho County. It further indicated that $\mathrm{CBC}$ promoted competencies including effective communication, lifelong learning and critical thinking. Hence, the assessment of CBC should be done at all levels consistently and continuously. The current study is in agreement with the study done in Rwanda by Rubagumya, Peeraer and Ntawigira(2018) on CBC implementation that has taken shape with the majority of teachers having been taught and gain knowledge in CBC.The competency-based curriculum in Rwanda emphasised continuous assessment methods rather exam based methods. The assessments are to assist in the identification, development and management of capabilities and skills of the learner. Communicating using verbal or non-verbal forms correctly in a number of contexts was one of the parameters that were used to measure $\mathrm{CBC}$ and its outcome.

In view of social relationships, learners show acceptable etiquette. According to the findings, the head teacher and Grade 1 teachers rated this outcome with a mean of 3.24 and 3.04 with a 
variation of 1.23 and 1.03 , respectively. Basing on these findings, it is an indication that learners have improved in terms of socialisation at both home and school. Respondents mentioned in the open-ended and interview schedule that communication and good etiquette have improved among the learners. In fact, one of the CSO said:

Socialisation and confidence were good. The element that there is no competition among learners, it has given them confidence because they see themselves as equals

Since there is no ranking in schools, this has boosted the children to be confident; it has also improved socialisation and self-expression. This current study was in agreement with a study done by Mulenga and Kabombwe (2019), which was done in Zambian Primary and Secondary Schools on a competencybased curriculum. It emphasised that the program is structured to help students develop awareness, talents, behaviours and values that are likely to empower them with skills hence helping them to serve society effectively. This is in agreement with the findings of the current study since the Kenyan curriculum caters to skills and talents which are practical oriented. In social relationships, this improves proper etiquette.

Creativity and critical reasoning skills in problemsolving in beginners was another CBC outcome parameter. This was rated with a mean of 3.86 and $3.79(S D=1.23$ and 1.03 respectively) for the head teachers and Grade 1 teacher. Basing on these findings, creativity and critical reasoning skills in problem-solving in beginners have been enhanced by the CBC curriculum. This was supported by qualitative data by a CSO who said that this parameter, critical thinking and creativity, has greatly improved. This was clearly stated by a CSO that:

During assessments of grade three, when they were cleaning the market, the learners were creative than the teachers and would go an extra mile to come up with masks and wheelbarrows by themselves. This surprised the teachers because the learners did more than them.

However, it was pointed out by Grade 1 teachers in open-ended questions that natural occurrences are factors that hinder outdoor activities for instance, rain. The teachers mentioned that too much rain affects outdoor activities for instance; physical health education, agricultural practices, art and craft practical were affected. This contributes negatively to the nurturing of talents hence affecting creativity and critical thinking negatively. The findings reveal that the learners have greatly improved in terms of creativity and critical thinking skills. In line with the World Bank (2019), this new analysis to succeed at work and in life, students must develop foundational knowledge and skills through core subjects like language, mathematics, and science, and they must also learn how to solve problems. This can be achieved through practical's that can be nurtured through creativity. This is important because it will lead to thinkers and self-driven individuals. This current study agrees with the study done by Rubagumya, Peeraer and Ntawigira (2018) in Rwanda. The competency-based curriculum emphasises the use of continuous assessments method to exam based. This reveals that the assessments are to assist in the identification, development, management of capabilities and skills of the learner. Creativity and critical thinking skills in problem-solving have been achieved through $\mathrm{CBC}$ in Kericho County.

Exploring immediate surroundings enjoying and learning by the learners revealed that the learners appreciate nature. The head teachers rated it at a mean of $2.86(S D=1.23)$, while Grade 1 teachers' mean was $2.81(S D=0.77)$. CBC has made learners value nature and its environment. This study concurs with one done by Moige (2018) on determinants of children's readiness for Grade 1 in Kisii Central Sub-County, Kenya. Family factors such as the preparation of the child to school from home, the encouragement of parents to child, the parents' participation in schoolwork, the financial status of the family, and the parent's level of education have an influence on children's readiness in Grade 1. Availability of materials, playing space and availability of sufficient physical facilities as the school factors also had an influence on the child's readiness to learning in Grade 1. This is an indication that for $\mathrm{CBC}$ to be successful learners needs to explore the environment when learning. This brings enjoyment during learning; hence objectives are achieved.

137 | This work is licensed under a Creative Commons Attribution 4.0 International License. 
In order to improve health and well-being, learners exercise hygiene, diet, sanitation and protection skills. This is an indicator that the learners have slightly improved in terms of health, diet, sanitation and protection skills. This was rated by the head teachers at a mean of $2.70(S D=0.97)$, while the Grade 1 teachers rated it at a mean of $1.72(S D=$ 1.01). Head teachers rated it slightly higher than the Grade 1 teachers. This was emphasised by a CSO when one of them mentioned that:

The lower classes started putting on masks, apron ready to clean the environment. They would clear the bushes and empty the stagnant water to avoid mosquitoes.

This is a clear indication that learners value hygiene and sanitation.

For a healthy life, learners show the acquisition of mental, aesthetic, moral development, spiritual and physical. This was one of the aspects of life to be achieved by learners. This was rated at a mean of 3.34 and 3.02 ( $S D=1.10$ and 1.22 respectively) for the head teachers and Grade 1 teachers. Based on the findings, it is evident that learners have improved in these aspects. During the interview, a CSO mentioned that "children have grown to be allrounded individuals". It was also stated by one of the CSO that "children have become creative and well balanced morally. The children value beauty, they are able to control emotion". This current study concurs with the one done in Kenya by Ogutu (2020) on the changing of creative art in promoting the growth of children in Kenya. This study revealed that there are diverse ways in which a creative art curriculum promotes the child's development and growth in the holistic development of a learner. Creative art is very important in the development of children and growth because it enhances nurturing of children's talents. This is one of the objectives of the competence-based curriculum. Learners express respect varied and rich cultural heritage of the world for harmonious coexistence. The findings were rated at a mean of $1.24(S D=1.04)$ and Grade 1 teachers had a mean of $1(S D=1.28)$. The findings show clearly that the learners have minimal knowledge of culture and heritage because academics have covered most of their time.

For learning and fun, learners' application of digital literacy skills was another outcome of CBC. This aspect was rated at a mean of $2.51(S D=1.22)$ by the head teachers, while the grade one teachers, with a mean of $2.59(S D=1.01)$. This is an indication that learners enjoy using integrated ICT during learning. The interview findings supported that, "The schools that are well established like the Tea Estate Schools enjoy using ICT. They are even allocated more time to integrate learning while in school". This study is in agreement with the one done by Mwololo \& Okinda (2019) carried out on determinants of Integration of ICT in Instruction in Early Childhood Education Programmes in Selected Universities in Kenya. The Lecturers' perceived ICT abilities were the best predictor of ICT integration in their instruction of ECE programmes. This is applicable during teaching and learning of lower primary

Table 2: Observation Results for Physical Infrastructure in Public Primary Schools in Kericho County

\begin{tabular}{lll}
\hline ITEM & Frequency (f) & Percentages (\%) \\
\hline Availability of ICT designed classroom or computer labs & 52 & 100 \\
Electricity power connection & 52 & 100 \\
Classroom for the learners & 52 & 100 \\
Music room & 6 & 11.54 \\
Nutritional labs & 8 & 15.38 \\
Creative arts room or workshop room & 10 & 19.23 \\
Reliable security room for computers storage & 45 & 86.54 \\
Library & 4 & 7.69 \\
Book store & 48 & 92.31
\end{tabular}

138 | This work is licensed under a Creative Commons Attribution 4.0 International License. 
From the observation schedule in Table 2, 50 $(100 \%)$ of the schools have ICT-designed classrooms, but they were small hence cannot accommodate large classes. All $52(100 \%)$ had an electrical power connection. It is a clear indication that the government has made an effort to fund public primary schools for electricity connection and provision of laptops which enabled the learners to integrate ICT. The availability of classrooms was sufficient;52 (100\%) have sufficient classrooms. The schools that had music rooms were 6 (11.54\%). The schools were planning to convert the old classrooms to accommodate the music rooms. Nutritional laboratories were $8(15.38 \%)$. These rooms were the old classrooms that were renovated to suit the CBC practical lessons. Creative arts rooms or workshops were 10(19.23\%) already renovated and were being used previously in 8:4:4 systems. That was the time when creative arts were examinable. From the observation on the reliability of secured storage rooms for computers or laptops, $45(86.54 \%)$ were available and adequate. This is an indication that the government has made an effort to fund public primary schools to construct storage rooms. The availability of Libraries was 4 (7.69\%) of the schools. Book stores were $48(92.31 \%)$ of the schools were available and adequate. Bookstores were adequate and available in schools compared to libraries.

A study was done by Kigwilu and Akala (2017) on utilisation of resources in curriculum implementation in community colleges in Kenya disagrees with this study that, as much as many institutions are faced with the challenge of the inadequacy of physical facilities and resources, the major challenge to the implementation of curricula was underutilisation of these resources and facilities by both teachers and learners. A study was done by Nturibi (2015) in Meru County, Kenya, concurs with the current study, which observed that there were not available or inadequate Home Science laboratories, creative art classes, music rooms, among other physical infrastructure, which affects the implementation of CBC negatively. This study further focused on performance where the school infrastructure inadequacy affects the performance of the primary school learners negatively. The schools should also have well-equipped libraries hence the need to equip libraries and build, for schools without libraries. The current study investigated $\mathrm{CBC}$ implementation in Kericho County.

\section{Physical Infrastructure and the Implementation of CBC in Public Primary Schools}

Objective one sought to establish the relationship between physical infrastructures on Competence based-curriculum implementation in Public Primary Schools in Kericho County. In order to investigate physical infrastructure on implementation of $\mathrm{CBC}$, head teachers' questionnaires, Grade 1 teachers' questionnaires and interviews were given to CSOs.

Table 3: Physical Infrastructure and the implementation of $\mathrm{CBC}$ in public primary schools in Kericho County

\begin{tabular}{|c|c|c|c|c|}
\hline \multirow[t]{2}{*}{ Reasons } & \multicolumn{2}{|c|}{$\begin{array}{l}\text { Head teachers } \\
(\mathbf{n}=\mathbf{5 0})\end{array}$} & \multicolumn{2}{|c|}{$\begin{array}{l}\text { Grade } \\
\text { teachers }(n=57)\end{array}$} \\
\hline & Mean & Std. Dev. & Mean & Std. Dev. \\
\hline $\begin{array}{l}\text { The computer labs or ICT Designed classrooms are suitable } \\
\text { for learners in my school }\end{array}$ & 3.66 & 0.94 & 3.18 & 1.04 \\
\hline There are enough classrooms for the learners & 3.69 & 1.04 & 4.02 & 1.03 \\
\hline There is a constant supply of electricity (main power) & 3.62 & 1.68 & 4.12 & 0.73 \\
\hline $\begin{array}{l}\text { The Electricity cables are well connected in the ICT designed } \\
\text { classroom or in computer laboratories }\end{array}$ & 2.80 & 1.44 & 3.44 & 1.18 \\
\hline $\begin{array}{l}\text { The Creative art classrooms or workshop rooms are adequate } \\
\text { for learning }\end{array}$ & 1.88 & 1.14 & 1.60 & 1.08 \\
\hline There are appropriate nutrition or Home science laboratories & 2.18 & 1.37 & 1.39 & 0.92 \\
\hline There is a well-equipped Music classroom in the school & 1.88 & 1.27 & 1.35 & 1.43 \\
\hline There is a sufficient agriculture farm in your school. & 2.22 & 1.39 & 2.30 & 1.43 \\
\hline There are agriculture tools and equipment in the school & 2.52 & 1.42 & 1.70 & 1.87 \\
\hline
\end{tabular}


Table 3 presents responses given by the head teachers and Grade 1 teachers on the influence of physical infrastructure on the implementation of $\mathrm{CBC}$ in public primary schools in Kericho County. The head teachers and Grade 1 teachers rated highly the suitability of the computer labs or ICT Designed classrooms for learners in their schools. The findings were rated at $3.66(S D=0.94)$ for head teachers and $3.18(S D=1.04)$ for Grade 1 teachers. This was further confirmed by qualitative data. All the CSOs, head teachers and Grade 1 teachers agreed that there should be extra classrooms to support the practical lessons and generally the implementation of CBC. This was further supported by one of the CSO who said:

Schools with extra old classrooms should utilise them for both class and artwork, though there is a crisis because of lack of special rooms for workshop and nutrition rooms due to increasing population among learners.

It was further confirmed by another CSO who said:

We have utilised most of the old classes to multitask so as to suit the practical lessons. The schools under James Finlay's company and Unilever Company have assisted in infrastructural development.

This is great support from these companies who are giving back the services to the community through education. They have assisted in constructing schools and in the provision of teaching and learning resources. Insufficient computers were mentioned by all the respondents. This was evident when Grade 1 teachers and head teachers revealed that, number of computers was not enough for the entire class because of the increasing enrolment. Some schools have some computers that need to be repaired, thus slows down the collaboration of technology in teaching and learning. Since CBC requires ICT integration, it is important to have adequate and reliable computers and networks. This will enable schools to achieve the desired goals or objectives per subject.

Availability and adequacy of classrooms was another important infrastructure. The head teachers and Grade 1 teachers rated it with a mean of 3.69 $(S D=1.04)$ for head teachers and $4.02(S D=1.03)$ for Grade 1 teachers. The interview indicated similar findings when it revealed that the majority of the schools have enough classrooms. This was further clarified by a CSO who said:

One thing we are fortunate in is the issue of classrooms. Most schools have sufficient classrooms for the learners. Though, we feel that some schools have overcrowded classes.

This disagrees with the study done in India by Chaudhary (2015), which revealed that create a curriculum development atmosphere to the central government should have physical amenities. These include libraries, laboratories and playground. The physical infrastructure is vital to the influence of academic performance in public primary schools in the Ruiru location. This finding disagrees with the study done by Nturibi (2015) on the Influence of School Infrastructure on Academic Performance in Public primary schools in Ruiru location, Kenya. This study revealed that classrooms were overcrowded and in poor condition. Many classes were not finished, not plastered or cemented on the floors.

Constant supply of electricity (main power) was another important aspect of CBC. It was also rated highly at $3.62(S D=1.68)$ and a mean of $4.18(S D$ $=0.73$ ) for head teachers and Grade 1 teachers, respectively. This was further supported by qualitative data. The Grade 1 teachers rated highly compared to the head teachers. This was confirmed by qualitative data. It was revealed that electricity was one of the items that have been successfully installed by the government and all the respondents appreciated the effort. This was confirmed by a CSO who said that:

The government had connected electricity to the majority of public primary schools to enable the ICT rooms to power the computers.

This is an added advantage in the CBC curriculum since it requires electricity to run the ICT programmes and also security lights in Schools.

Electricity cables connection in the ICT-designed classroom or in computer laboratories had a mean of $2.80(S D=1.44)$ and a mean of $3.44(S D=1.18)$ for both the head teachers and Grade 1teacher, respectively. The number of computers was not enough for the entire class because of the increasing

140 This work is licensed under a Creative Commons Attribution 4.0 International License. 
enrolment. Some schools have some computers that need repair, thus slow down the collaboration of technology in teaching and learning. The network issue was a challenge in some schools, such that the lessons were interrupted. In fact, one of the head teachers said that:

The biggest challenge is that during ICT lessons, the network is interrupted causing some of these lessons to end prematurely.

This is a clear indication that for ICT integration in every topic, there is a need to have enough computers, proper ICT maintenance and an uninterrupted network.

The adequacy of Creative art classrooms or workshop rooms for learning was rated lowly by both the head teachers and Grade 1 teachers at a mean of $1.88(S D=1.14)$ and a mean of $1.60(S D=$ 1.08). Concerning how appropriate nutrition or Home science laboratories in the schools are the head teachers and Grade 1 teachers rated it with a mean of $2.18(S D=1.37)$ and $1.39(S D=0.92)$, respectively. Well-equipped Music classrooms in the schools were rated lowly by both the head teachers and Grade 1 teachers with a mean of 1.88 $(S D=1.27)$ and mean of $1(S D=1.43)$, respectively. This was confirmed by qualitative data where it was mentioned that laboratories were a necessity when it came to CBC implementation. All the respondents commented that, for $\mathrm{CBC}$ to be successful, it is important to have all these laboratories to ease a practical lesson that is part of the curriculum. One CSO said that:

Workshops, home science, music classrooms should be built and farm tools should be availed in schools.

ICT rooms should be spacious enough to accommodate the large increasing numbers of learners. ICT technicians should be employed to assist in schools. This is because the head teachers believed the ICT rooms are too small to accommodate the classes. This is in agreement with the study done in India by Chaudhary (2015), which indicated that in order to establish an atmosphere where curriculum development can take place, physical amenities should be provided by the central government. It also concurs with the study by Muasya and Waweru (2019) in Machakos County on the challenges facing the successful implementation of $\mathrm{CBC}$. It revealed that learning resources available in institutions were not sufficient in comparison to the number of learners.

On the availability of agriculture farms in the schools, the head teachers rated it at $2.22(S D=$ 1.39), while the Grade 1 teachers rated it with a mean of $2.30(S D=1.43)$. The sufficiency of agriculture tools and equipment was rated by the head teachers and Grade 1 teachers at a mean of 2.52 and $1.70(S D=1.42$ and 1.87 , respectively). Provision of enough agricultural land is very important in the study because it is a practical oriented, programme but unfortunately, most schools lack these based on the findings. This was confirmed by open-ended questions from qualitative information. This was clearly stated that there was a big challenge in most schools with insufficient land for agriculture. This was further indicated by the head teachers that in their schools, they share the land with their neighbouring secondary schools. This makes some of the lessons and activities clash with their programmes.

For CBC to be successful, since its practical oriented, there is a need to have enough land for agricultural practical tools and equipment should also be provided to all schools. On the other hand, this affects activities in the playing fields to be used for sports. To nurture talents a requirement in CBC, it is important to have enough space for field activities. This was indicated by the head teachers who pointed out that children need a wellmaintained spacious field for sports and playing materials to promote outdoor activities. The purchasing of teaching and learning resources should also be prioritised, especially for practical work. Tea estate schools are fortunate because the companies meet the purchasing of teaching and learning resources for the schools, especially those under Finlay's company and Unilever Company. These findings concur with the study done by Kigwilu and Akala (2017). Learning and teaching resources, for instance, course books, lecture rooms, workshops, laboratories and raw materials for practical training, were found to be adequate, although underutilised. The provision of resources was supported by the immediate companies. CBC and influence of physical infrastructure results were 
further analysed using Person product-moment correlation.

Table 4: The Relationship between Physical Infrastructure and Implementation of Competencebased curriculum

\begin{tabular}{lll}
\hline & Physical Infrastructure & $\begin{array}{l}\text { Implementation of Competence- } \\
\text { based curriculum }\end{array}$ \\
\hline Physical Infrastructure & Pearson Correlation & $+0.336^{*}$ \\
& Sig. (2-tailed) & 0.029 \\
& $\mathrm{~N}$ & 50 \\
Physical Infrastructure & Pearson Correlation & $+0.285^{*}$ \\
& Sig. (2-tailed) & .032 \\
& $\mathrm{~N}$ & 57 \\
\hline
\end{tabular}

*. Correlation is significant at the 0.05 level (2-tailed).

Table 4 reveals the relationship between physical infrastructure and the implementation of a competence-based curriculum. Head teachers' correlation was +0.336 with a calculated $p$-value of 0.029 . It was a clear indication that it was a moderate positive influence according to the interpretation given by Leedy and Ormrod (2005). The set $p$-value was $p<0.05$, which means any value below the set value is significant. Hence, the calculated value is significant. Grade 1 teacher's correlation was +0.285 with a calculated value of 0.03 ; hence this was a moderate positive influence because the calculated $\mathrm{P}$-value is significant. Therefore, the relationship between physical infrastructure and implementation of Competencebased curriculum Implementation is significant. Hence, the alternative hypothesis is accepted. This means physical infrastructure influence the implementation of CBC positively.

The current study concurs with a study done in South Nigeria by Akomolafe and Adesua (2016), which indicated that there was a positive relationship between student motivation level as well as academic performance with physical amenities. Therefore, a better quality of adequacy of physical material and human resources motivated students hence improving the academic performance. It also concurs with the study done in Arusha City, Tanzania by Kanyonga et al. (2019), revealing that the challenges included inadequate human resources and physical material for implementation. It also agrees with the study by Kigwilu and Akala (2017), which found that teaching and learning facilities, such as classrooms, machinery, lecture rooms, labs, practical training raw materials and reference books, were sufficient, although underutilised. It is necessary,therefore, to ensure all the physical infrastructure are availed in schools since it has an influence on the successful implementation of CBC.

This was also pointed out clearly by the teachers in their open-ended questions that $\mathrm{CBC}$ training added more skill and knowledge in the profession. The competence of a teacher is important in that they should have skills and knowledge to teach the learners. The head teachers and CSOs indicated that training on CBC should be fast-tracked. This is because they felt that when the training is complete, the teachers will be more effective and conversant. In fact, one of the CSO said:

Since there is a set programme in every session to train teachers, we intend to ensure that all teachers should be CBC compliant by the end of this year.

This was an assurance that by providing consistent training such that most teachers will be well equipped.

This disagrees with a study done by Ondimu (2018) on teachers' preparedness for CBC implementation in private pre-school in Dagoretti North Sub County Nairobi. The results found that most of the head teachers and pre-school teachers completed inservice instruction, but most of them decided that they were able to adapt to the CBC program. That 
demonstrates that most of the teachers were adequately trained and equipped with knowledge of the subject content. It also concurs with the study carried out by Momanyi and Rop (2019), which showed that teachers are poorly trained. Their comprehension of $\mathrm{CBC}$ is unclear and their implementation and assessment have been impaired by this.

Computer training is necessary to improve teachers' delivery of ICT integration. The head teachers rated it with a mean of $3.12(S D=1.38)$, while Grade 1 teachers had a mean of $2.95(S D=1.31)$. The head teachers rated it highly compared with Grade 1 teachers on having basic knowledge of computers. Similarly, the use of the internet to integrate learning was rated at a mean of $2.95(S D=1.38)$ by the head teachers. Grade 1 teachers had a mean rate of $3.53(S D=1.31)$. Grade 1 teachers rated the use of the internet to integrate learning highly compared to the head teachers. The interview findings reveal that most teachers are not well conversant with the use of computers. This was clarified by a CSO who said:

During the assessment, teachers pretend to integrate ICT during the teaching and learning process. It evident that further training is required.

To improve on the integration of ICT training of teachers is very important to enhance efficiency and confidence.

It disagrees with a study undertaken by Nasara and Agbo (2019) on the comparative level of expertise needed in computer use in the assisted design for pattern drafting in Nigeria by lecturers and students. The study found out that in teaching and studying pattern drafting using Computer Assisted Design for pattern drafting, both lecturers and students have low levels of competence. In order to boost computer training in Computer Assisted Design for pattern drafting in tertiary institutions in Nasarawa Province, Nigeria, the study proposed that school administration should have effective personnel development policies. It also disagrees with the research undertaken by Ondimu (2018). The study showed that most teachers were not introduced to ICT and that most were not qualified because they lacked technical knowledge. This coincides with the research conducted by Ngeno et al. (2020). It demonstrated that the training of computer teachers that was done in May 2015 did not appeal to all the teachers in the sector. The study found out that the government wanted to conduct workshops and inservice services to cater to teachers who are still in the sector but are non-compliant with computers.

Training on learner assessment basing on the new curriculum was rated at a mean of $3.22(S D=1.02)$ by the head teachers, while Grade 1 teachers had a mean of $3.69(S D=1.09)$. Grade 1 teachers rated it slightly higher than the head teachers. This was further revealed during the interview that teachers had been trained on the assessment of the curriculum. It was cited that:

Training on assessment has been done, but some teachers need to be trained for smooth implementation of $C B C$.

The teachers mentioned that an Examination of the curriculum at all levels should be done. Teachers mentioned that there is a need to examine the CBC curriculum at every level for healthy completion among learners. This could be one of the core reasons teachers have a negative attitude towards the new curriculum. Since 8-4-4 was exam-oriented, the teachers felt like the students needed to be examined so that they are able to determine the learners' ability. This concurs with the study done by Waweru (2018) on the influence of CBC implementation on teacher preparedness in public primary schools in Nyandarua Sub -County Kenya. This study recommended that training programmes should be carried out by the ministry of education on assessment, lesson preparation and infusion. $\mathrm{CBC}$ instructional materials should be delivered to schools on time to facilitate instruction. Training teachers on assessment is very important because it enables teachers to do a proper evaluation of learners' progress.

\section{CONCLUSION AND RECOMMENDATION}

Basing on the findings, the following conclusions were made; physical infrastructures are critical in the implementation of the competency-based curriculum. There was a moderate positive relationship between the physical infrastructure and $\mathrm{CBC}$ as given by the head teachers with a correlation of +0.336 . This is a moderate positive 
influence. For Grade 1 teachers, it was +0.029 . This was a weak positive influence. The other factors that influenced the implementation of $\mathrm{CBC}$ are provision and construction of laboratories, music room, creative arts, and expansion of libraries, playing materials, provision of agricultural tools, expansion of ICT rooms and more space in the field to allow physical activities. This study concludes there is a need to fund schools so that they can improve on physical infrastructure

The study recommends further research to be done on the effects of teachers' related factors in the implementation of CBC programmes.

\section{REFERENCE}

Akomolafe, C. O., \& Adesua, V. O. (2016). The Impact of Physical Facilities on Students' Level of Motivation and Academic Performance in Senior Secondary Schools in South-West Nigeria. Journal of Education and Practice, 7(4), 38-42.

Ashiono, B. (2018). Determinants of Information and Communication Technology Integration in Learning of Numeracy Concepts in Lower Primary Schools in Mombasa County, Kenya.Kenyatta University Institutional Repository.

Chaudhary, G. K. (2015). Factors affecting curriculum implementation for students. International journal of applied research, 1(12), 984-986.

Christensen, N. \& Lane, J. (2016). Know-DoUnderstand: Development of competencies in Canada's schoolchildren. Canada West Foundation.

Council of Governors. (2019). Consultative Forum on the competence-based curriculum and the vocational training centres conditional grants guideline. Nairobi: News Highlights.

Dewey, J. (1938). Experience and education. New York: Macmillan

European Union. (2018). Teaching and Learning in Primary Education. Retrieved on $14^{\text {th }}$ September 2018 from https://eacea.ec.europa.eu/national- policies/eurydice/content/teaching-and-

learning-primary-education-20_en

Forum for Research and Policy in Communications (2020).

Hernández-de-Menéndez, M., \& MoralesMenendez, R. (2017, June). Competency Based Education-Current Global Practices. In Proceedings of the 3rd International Conference on Higher Education Advances (pp. 1156-1163). Editorial Universitat Politècnica de València.

Jadhav, M. S., \& Patankar, P. (2013). Role of Teachers in Curriculum Development for Teacher Education. PaperPresented on the National Conference, Challenges inTeacher Education, Physical Education and Sports: Teachersas Curriculum Developers

Kanyonga, L., Mtana, N., \& Wendt, H. (2019). Implementation of competence-based curriculum in technical colleges: The case of Arusha City, Tanzania. International Journal of Vocational and Technical Education, 11(1), 120.

KICD. (2017). Facilitator's Training Manual for Early Years Education Curriculum. Nairobi; Kenya: Kenya Institute of Curriculum Development.

Kigwilu, P. C., \& Akala, W. J. (2017). Resource utilisation and curriculum implementation in community colleges in Kenya. International Journal for Research in Vocational Education and Training (IJRVET), 4(4), 369-381.

Kothari, C.R. (2004). Research methodology. Methods and techniques (2nd revised).

Leedy, P. \& Ormrod, J. (2005). Practical Research Planning and Design. Prentice Hall, Upper Saddle River, NJ.

Michel, A. (2017). The contribution of PISA to the convergence of education policies in Europe. European Journal of Education, 52(2), 206-216.

Moige, O. N. (2018). Determinants of Children's Readiness for Grade 1, in Kisii Central Sub-

144 | This work is licensed under a Creative Commons Attribution 4.0 International License. 
county, Kenya. Dissertation, Kenyatta University.

Momanyi, J. \& Rop, P. (2019). Teacher Preparedness for the Implementation of Competence-Based Curriculum in Kenya: A Survey of Early Grade Primary School Teachers in Bomet East Sub-County. African Journal of Educational and Social Science Research,7(1),10-15.

Muasya E. W., \& Waweru S. N. (2019). Constraints Facing Successful Implementation of the Competence-Based Curriculum in Kenya. American Journal of Educational Research. 2019, 7 (12), 943-947.

Mulenga, I. M., \& Kabombwe, Y.M. (2019). A Competence-Based Curriculum for Zambian Primary and Secondary Schools: Learning from Theory and some Countries around the World. International Journal of Education and Research, 7(2), 117-130.

Mwololo Waema, T., \& Okinda, O. (2011). Policy Implications of the Relationship between ICT Access and Usage and Well-being: A Case Study of Kenya.

Nasara, E.S., \&Agbo, D.A. (2019). A Comparative Study on Level of Competence Required By Lecturers and Students in the Use of ComputerAided Design for Pattern Drafting inTertiary Institutions Nasarawa State, Nigeria. International Journal of Research and Innovation in Social Science (IJRISS, 3(7), 41923.

Ngeno, B. C., Sang, H. C., \& Chemosit, C. (2020). Teachers' Computer Literacy in Selected Public Primary Schools in Ainamoi Sub-County in Kericho County, Kenya. East African Journal of Education Studies, 2(1), 1-7.

Nturibi, P. R. (2015). Influence of School Infrastructure on Academic Performance in Public Primary Schools in Ruiri Location-Meru County, Kenya. Unpublished Master Thesis. University of Nairobi

Ogutu, W. (2020). The Dynamics of Art and Craft Curriculum in Enhancing Child Growth and
Development. East African Journal of Education Studies, 2(1), 18-24.

Ondimu, S. (2018). Teachers' preparedness for Implementation of the Competency Based Curriculum in Private Pre-Schools in Dagoreti North Sub-County, Nairobi City County. Nairobi; Kenya: University of Nairobi.

Republic of Kenya. (2017). Basic Education Curriculum Framework. Nairobi; Kenya: Kenya Institute of Curriculum Development.

Rubagumya, E., Peeraer, J. \&Ntawigira, E. (ed). (2018). Implementation CBC: Successes and Challenges. Kigali, Rwanda. UrunanaRw'abarezi,6, 6-9.

UNESCO. (2015). Evolution of Curriculum Systems to Improve Learning Outcomes and ReduceDisparities in School Achievement. The Education for All Global. International Bureau of Education.

Vallejs, N., Morel, G., \&Tusing, J. (2017) Implementation of competency-based curriculum: College of Philosophy, Universidad Nacional del Este, Paraguay. The Journal of Competency Based Education, 2(1), e01038.

Wanjohi, A.M. (2018). Critical Review of 8-4-4 Education System in Kenya. Schools Net Kenya.

Waweru, J.W. (2018). Influence of Teacher Preparedness on Implementation of Competence Based Curriculum in Public Primary Schools in Nyandarua North Sub-County, Kenya. University of Nairobi.

World Bank. (2019). Learning Assessment Platform (LeAP). World Bank Group. https://www.worldbank.org/en/topic/education/ brief/learning-assessment-platform-leap

145 | This work is licensed under a Creative Commons Attribution 4.0 International License. 